\title{
Research on Teaching and Examination Mode of Organic Analysis Course under "Ideological and Political Theories teaching in All Courses (IPTTAC)" Background
}

\author{
Hongjie $\mathrm{Qu}^{*}$, Yafei Wang, Fengying Xu
}

\author{
College of Science, Heilongjiang Bayi Agricultural University, Daqing, 163319, Heilongjiang Province, P. R, China
}

DOI: $10.36347 /$ sjavs.2021.v08i05.001

| Received: 26.03.2021 | Accepted: 04.05.2021 | Published: 08.05.2021

*Corresponding author: Hongjie Qu

\section{Abstract}

Moral education is an important part of quality-oriented education as well as the fundamental task of higher education; and "Ideological and Political Theories teaching in All Courses (IPTTAC)" is an important way to cultivate people. This course on the basis of the IPTTAC ideas take the case teaching, and to dig deeper into the IPTTAC elements, at the same time into the frontier achievements and social hot-spots and design experiment, and flip the classroom teaching methods and research-oriented teaching, to cultivate the students' home countries feelings, ability of scientific thinking and moral quality training and the team cooperation ability.

Keywords: Organic Analysis; Ideological and Political Theories teaching in All Courses; examination mode.

Copyright $(\mathcal{2 0 2 1}$ The Author(s): This is an open-access article distributed under the terms of the Creative Commons Attribution 4.0 International License (CC BY-NC 4.0) which permits unrestricted use, distribution, and reproduction in any medium for non-commercial use provided the original author and source are credited.

\section{INTRODUCTION}

"We must continue to take moral education as the central link, put ideological and political work through the whole process of education and teaching, and achieve all-round education", this is what General Secretary $\mathrm{Xi}$ stressed at the National Conference on Ideological and Political Work in Colleges and Universities. The quality education of moral education not only exists in the moral education class, but also runs through the whole teaching. No matter what subjects are taught, the teaching content is permeated with moral elements, so that students' thoughts can be well influenced in the process of learning professional knowledge, so as to set up correct thoughts and cultivate good moral character. In the teaching process of this course, the content of ideological and political education should be naturally and organically integrated, so that ideological and political education and the courses taught can have a "chemical reaction"[1]. The copy-pasted instilling teaching of teachers will greatly reduce the enthusiasm and learning effect of students and make the classroom atmosphere dull and dull [2]. The introduction of Ideological and Political Theories teaching in All Courses (IPTTAC) can well activate the classroom atmosphere. Classroom has the function of educating people, and teachers have the duty of educating people, so it is necessary to combine professional teaching with ideological and political teaching organically, and at the same time integrate scientific view and scientific method into the classroom of higher education, so as to cultivate students' scientific cognitive spirit and improve the quality of student talent training.

\section{Element mining of IPTTAC in Organic Analysis}

Ideological and Political Theories teaching in All Courses (IPTTAC) is neither a great emphasis on ideological and moral cultivation, nor a special emphasis on domestic and foreign political theories, but refers to the course teaching and ideological politics in the same direction, forming a synergistic effect. In the new era of the field, organic chemistry has a high degree of activity, for the analysis of organic material is also a research and application of the hot-spot. Organic Analysis is a theoretical and practical course, is one of the important courses of applied chemistry major, is the application of analytical chemistry in the field of organic chemistry, is an important part of analytical chemistry. There are four IPTTAC factors in Organic Analysis, which are "telling Chinese stories well" to cultivate students' feelings of home and country; "telling good master stories" to cultivate students' consciousness of seeking truth in scientific research; "telling good stories around" to train students to be good at observation and discovery thinking; and the integration of scientific concept and scientific methods, to train students' scientific cognitive spirit, improve the quality of student talent training, to achieve the "wind 
into the night, moisten things silently" teaching and learning mutual suitability [3].

Organic Analysis course content involves the food, chemical engineering, medicine and pesticide, and other fields, and the structure of the organic matter referred to in the qualitative or quantitative analysis, the project will be relevant in the design of "knowledge" into teaching, excavate ideological elements should pass course team to discuss, and combined with professional knowledge nature, improve students benefited range. This teaching design will be correct ideological values into the middle of the classroom, professional knowledge and ideological and political education closely linked, in order to cultivate all-round talents with both integrity and ability [4].

\section{Tell Good Stories qround Us}

For the "determination of protein content in food" this knowledge point, the protein in food is composed of various amino acids, and the relatively stable element in the content of amino acids is nitrogen, the determination of nitrogen content in food can be directly converted to the content of protein. However, there are some profiteering businesses to add more nitrogen-rich chemicals to the food to improve the protein content of the food to show that the product is of "high" quality. For example, in the infamous "Sanlu" milk powder incident in recent years, those merchants forgot their interests and added melamine with high nitrogen content to milk powder to increase the nitrogen content of milk powder and effectively improve the detection amount of protein in milk powder. However, long-term intake of melamine can cause damage to the reproductive and urinary systems, causing bladder and kidney stones, and further induce bladder cancer. As a result, many children develop kidney function and urinary tract diseases. Classroom on this issue education students, do anything all "speak good faith", can not lose their faith in the interests of the front. As Mencius said, "Honesty is based on the unity of man and nature and the theory of goodness. No way is honesty." This tells the students that "honesty is the road, with the footsteps of the pioneers to extend; honesty is wisdom, with the accumulation of scholars seeking; honesty is success, with the advance of the struggle is approaching; and honesty is the seed of wealth, as long as you sincerely planted, you can find the key to open the Treasury"[5].

\section{Tell a Good Master Story}

One of the reduction methods of aldehyde and ketone is the Wolff-Kishner-Huang min lon-Reduction reaction. Wolff-Kishner first makes aldehyde and ketone react with hydrazine to produce hydrazone, and then coheat with sodium hydroxide or sodium alcohol at $180^{\circ} \mathrm{C}$ in a closed tube autoclave to reduce hydrazone to hydrocarbon. Minglong Huang is China's famous chemist, his reaction conditions on the basis of the reduction method is improved, the first three glycol, aldehydes or ketones, sodium hydroxide, and heating reflux $1 \mathrm{~h}$, hydrazine hydrate to aldehydes or ketones into hydrazone, then steamed out excess water and unreacted hydrazine, to achieve the hydrazone decomposition temperature (about $195 \sim 200{ }^{\circ} \mathrm{C}$ ) continue to return the $3 \sim 4 \mathrm{~h}$, obtain the restored product. This method successfully avoids the hydrazine anhydrous used in the Wolff-Kishner method, which not only widens the reaction conditions and shortens the reaction time, but also greatly improves the reaction yield, which can reach $90 \%$.

The organic reduction reaction modified by Minglong Huang, "Huang min lon Reduction Method", is the only reaction in the history of organic chemistry named after Chinese people, and it also changed people's view of China. In 1924, he received a doctor's degree in chemistry from the University of Berlin, Germany. In 1925, Minglong Huang resolutely returned to China and led the development of megestone and other family planning drugs, making great contributions to the establishment of the steroid drug industry. In 1982, he won the second prize of the National Natural Science Prize and published more than 100 research papers on the synthesis and reaction of steroids.

Students to learn from the masters of scientific research and true-seeking attitude, we have been China has such an achievement of chemical masters and feel proud.

\section{Tell a Good Story about China}

As a typical aromatic hydrocarbon, toluene can undergo nitrification reaction, resulting in trinitrotoluene, which is commonly known as TNT high explosive. Explosives are not only used in the military and national defense, but also in the fireworks and crackers to celebrate festivals. But we must buy regular products, and can be used correctly, otherwise it will bring negative effects, and even pay a painful price.

Speaking of explosives, this is also what we Chinese people are proud of. Gunpowder was invented by the Chinese people in the Tang Dynasty more than one thousand years ago, far ahead of the world! Later, researchers from all over the world continued to explore various new formulas to enhance the explosive power and safety performance, and successively invented nitroglycerin, mercury fulminate, cyclonite and other explosives. Now, Professor Hu Bingcheng's team from Nanjing University of Science and Technology in China has synthesized total nitrogen anionic salt for the first time. The explosive energy of total nitrogen anionic salt material can reach $3 \sim 10$ times that of TNT explosive, which can make a soldier $80 \mathrm{~mm}$ rocket launcher hit the power of $155 \mathrm{~mm}$ plus howitzer. High-performance energetic materials can not only be used to manufacture explosives. It is also the key technology of the next generation carrier rocket, which is expected to greatly improve the performance of carrier rocket. After 
thousands of years, the Chinese have finally returned to the position of world leader!

Students, must seize the opportunity, indomitable!Gunpowder is not only for fireworks, but also to use gunpowder to blow out a new world!

\section{Classroom Instruction \\ Flipped Classroom}

Part of the organic analysis classroom teaching content under IPTTAC will adopt the flipped classroom teaching method. In teaching, teachers not only integrate their own ideological and political elements, but also divide students into groups to conduct research teaching. Each group selected different chemical fields to search for literature, collect relevant images, conduct group discussion and in-depth exploration, and integrate ideological and political summary, which were presented in Microsoft Office PowerPoint(PPT) after sorting out. At the same time, a group of students will write an essay, and each student will write an essay about the exploratory learning. This teaching method can cultivate students' learning style of exploring and discovering problems, stimulate students' thinking potential, expand students' methods of solving problems, cultivate students' innovative consciousness, innovative spirit and innovative ability, and also enhance students' coordination and cooperation ability and teamwork consciousness.

\section{Experimental Teaching}

This course is a professional course that combines theoretical teaching with experimental teaching. The experimental items are selected for the synthesis, extraction or analysis of the accessible substances in life. Students are allowed to discuss part of the experiments by themselves to form a designed experiment. Experiment 1 is "Determination of protein content in food", raw materials for daily consumption of soybean powder and milk powder; Experiment 2 is "Ultraviolet Spectrophotometry determination of Vitamin C content", raw materials for daily vegetables (green pepper or tomato) and fruit (orange or lemon); Experiment 3 is "Acetyl chloride-NaAc-acetylation method to determine the content of polyols", raw materials for glycerol glycerol and propylene glycol. Based on theoretical knowledge, the experiment is designed by students themselves to cultivate students' scientific thinking logic. The experiment scheme is designed with raw materials close to life, so as to cultivate students' idea that knowledge comes from life and can be integrated into life, thus cultivating students' ability to combine theory with practice.

\section{Reform of Assessment Method of Organic Analysis under IPTTAC}

The organic analytical teaching under IPTTAC is integrated with students' research teaching and designed experiments. Therefore, the corresponding assessment method is reformed from the traditional two-factor assessment (class performance and final examination paper) to the multi-factor comprehensive assessment. The total score for the examination is 100 points: $70 \%$ for theory and $30 \%$ for experiment. The theoretical part includes $5 \%$ of professional assignments, and $30 \%$ of ideological and political assignments (PPT presentation $15 \%+$ exposative essay $10 \%$ + thoughts $5 \%$ + final exam 35\%). Achievements: Student achievement for the team as unit, display customize PPT, video and discussed in the field of the article. To be sure, according to different, each group member pay will be multiplied by the corresponding in the corresponding evaluation coefficients $(0.8 \sim 1.2)$, in order to reflect their contribution and the relationship between the scores, plus the IPTTAC activity of personal experience. The course assessment structure is shown below.

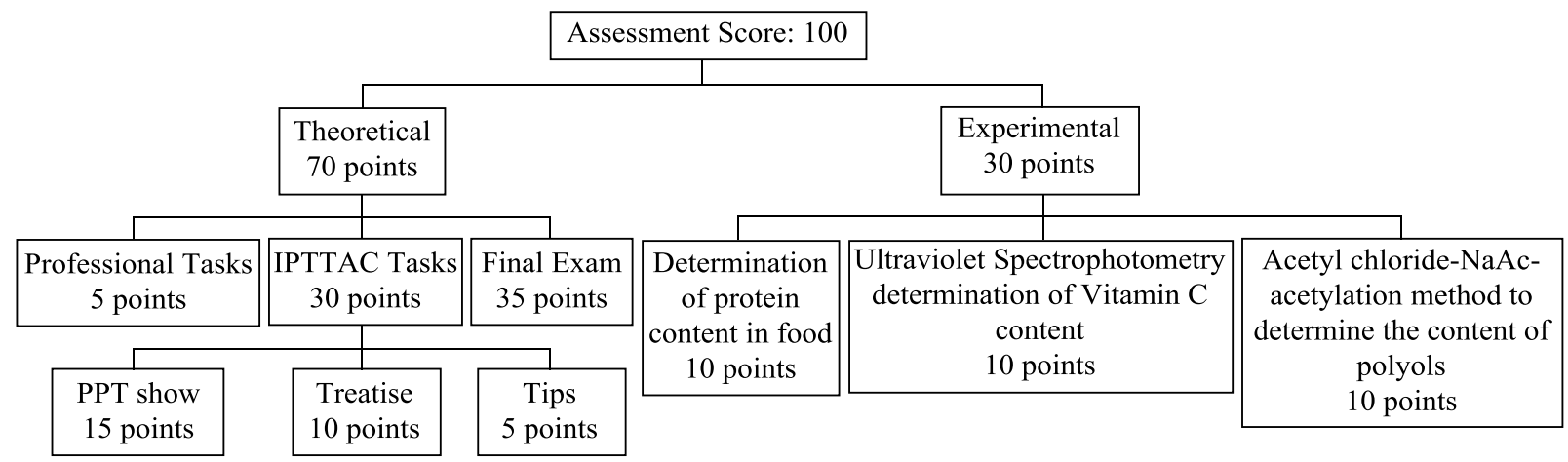

\section{Concluding Remarks}

Organic analysis is a required course for applied chemistry majors in agricultural colleges and universities, and IPTTAC runs through the course teaching. This course not only provides students with solid professional knowledge reserve, but also, as the carrier of IPTTAC, cultivates students' patriotism, scientific thinking ability, moral quality cultivation and teamwork ability. The inclusion of IPTTAC in this major course can help students establish a correct outlook on life, values and world outlook, and cultivate national pillars with morality and talent. 


\section{Fund Project}

"IPTTAC" teaching reform project of Heilongjiang Bayi Agricultural University in 2020, course title: Organic Analysis.

\section{REFERENCE}

1. F. Wan, Z. Wang, J. Gao, Y. Li, C. Li, L. Jiang, S. Ai, L. Zhang. (2020). Construction and Practice of Ideological and Political Teaching Model in Agricultural Organic Chemistry Course under the Idea of Building Morality and Cultivating People[J], University Chemistry, 35(X): 1-7.

2. Y. Wu. (2018). Building China's "Gold Class" $[\mathrm{J}]$, China University Teaching, (12): 4-9.
3. D. Duan, H. Zeng. (2021). Instructional Design Case Study on the Course Ideology and Politics in Organic Chemistry: Taking Alkaloid as an Example [J], University Chemistry, 36 (X):1-7.

4. G. Han, R. Liu, J. Guan. (2019). Exploration of Organic Chemistry Teaching under the Background of Course Ideology and Politics [J], University Chemistry, 34(11): 56- 60.

5. P. Tang, Z. Wang, L. Tao, X. Qin, G. Wu, Q. Chen, H. Cai. (2019). Exploration and Practice of Flipped Classroom in Pesticide Science $[\mathrm{J}]$, Journal of Yunnan Agricultural University (Social Science), 13(5): 129-133. 